\title{
Tomato plant inheritance of antixenotic resistance to tomato leafminer
}

\author{
Adilson de Castro Antônio(1), Derly José Henriques da Silva(2), Marcelo Coutinho Picanço(3), \\ Nerilson Terra Santos ${ }^{(4)}$ and Maria Elisa de Sena Fernandes ${ }^{(2)}$
}

\begin{abstract}
(1)Universidade Federal de Viçosa (UFV), Campus Florestal, Rodovia MG 818 Km 6, CEP 35690-000 Florestal, MG, Brazil. E-mail: adilson@ufv.br (2)UFV, Departamento de Fitotecnia, Genética e Melhoramento de Plantas, CEP 36570-000 Viçosa, MG, Brazil. E-mail: derly@ufv.br, mariaelisasena@yahoo.com.br (3)UFV, Departamento de Biologia Animal. E-mail: picanco@ufv.br (4)UFV, Departamento de Estatística. E-mail: nsantos@ufv.br
\end{abstract}

\begin{abstract}
The objective of this work was to determine the inheritance of resistance by antixenosis in tomato plants (Lycopersicon esculentum) to tomato leafminer [Tuta absoluta (Lepidoptera: Gelechiidae)]. Evaluations were performed for tomato plants of the generations $\mathrm{P}_{1}, \mathrm{P}_{2}, \mathrm{~F}_{1}, \mathrm{~F}_{2}, \mathrm{RC}_{1}$ and $\mathrm{RC}_{2}$. The measured characteristic in the parents, BGH-1497 ( $\mathrm{P}_{2}$ male) and 'Santa Clara' ( $\mathrm{P}_{1}$ female), and in the $\mathrm{F}_{1}, \mathrm{~F}_{2}, \mathrm{RC}_{1}$ and $\mathrm{RC}_{2}$ generations was the number of eggs per plant. This number was converted to the oviposition nonpreference index. The inheritance of antixenosis resistance of genotype BGH-1497 is ruled by a gene of greater effect and polygenes in epistatic interactions, with a phenotypic proportion of 13:3 between susceptible and resistant genotypes, respectively.
\end{abstract}

Index terms: Lycopersicon esculentum, Tuta absoluta, genetic resources.

\section{Herança da resistência antixenótica de tomate à traça-do-tomateiro}

\begin{abstract}
Resumo - O objetivo deste trabalho foi determinar a herança da resistência por antixenose em plantas de tomate (Lycopersicon esculentum) à traça-do-tomateiro [Tuta absoluta (Lepidoptera: Gelechiidae)]. As avaliações foram realizadas em plantas de tomate das gerações $\mathrm{P}_{1}, \mathrm{P}_{2}, \mathrm{~F}_{1}, \mathrm{~F}_{2}, \mathrm{RC}_{1}$ e $\mathrm{RC}_{2}$. A característica medida nos pais, BGH-1497 (masculino $\mathrm{P}_{2}$ ) e 'Santa Clara' (feminino $\mathrm{P}_{1}$ ), e nas gerações $\mathrm{F}_{1}, \mathrm{~F}_{2}, \mathrm{RC}_{1}$ e $\mathrm{RC}_{2}$ foi o número de ovos por planta. Este número foi transformado em índice de não preferência por oviposição. A herança da resistência por antixenose do genótipo BGH-1497 é governada por um gene de efeito maior e poligenes em interações epistáticas, com uma proporção fenotípica de 13:3 entre genótipos suscetíveis e resistentes, respectivamente.
\end{abstract}

Termo para indexação: Lycopersicon esculentum, Tuta absoluta, recursos genéticos.

\section{Introduction}

The tomato leafminer Tuta absoluta (Meyrick) (Lepidoptera: Gelechiidae) is one of the major pests attacking the commercial tomato (Lycopersicon esculentum Mill.), and it occurs in most South American countries (Leite et al., 2004). The larvae damage the leaves creating perforations in the form of galleries, since they feed on mesophyll tissues (França et al., 2000). New shoots, flowers and fruits are also attacked (Michereff Filho \& Vilela 2001).

This pest is controlled with the use of insecticides, which may lead to insect resistance, decrease natural enemies and increase production costs (Siqueira et al., 2000). Alternative methods to replace chemical control have been used, such as genotypes of resistant tomato plants (Toscano et al., 2002). Hence, the genetic resources of tomato plants have been evaluated for use as possible sources of resistance (Moreira et al., 2005).
Plant resistance may occur by antixenosis and antibiosis mechanisms. Antixenosis is characterized by lower utilization of the host by insects, for food, oviposition and shelter (Fancelli et al., 2005, 2008). There may be several causes for this mechanism, which can be chemical (Frelichowski Junior \& Juvik, 2005; Resende et al., 2008), physical (Khush \& Panda, 1995) and morphological (Dhillon et al., 2005), and may influence oviposition, nutrition and permanence of the insect on a plant.

According to Duvick (1986), the use of genetic resources plays an important role in breeding programs to obtain insect-resistant plants. Resistant genotypes are routinely used to breed pest-resistant cultivated plant varieties, and also to maintain insect population at an acceptable level (Vendramim \& Nishikawa, 2001). The use of genetic resources of cultivated L. esculentum maintained in the germplasm banks is an alternative to recover the lost genetic variability,

Pesq. agropec. bras., Brasília, v.46, n.1, p.74-80, jan. 2011 
in order to improve plant resistance to pests (Oliveira et al., 2009). In addition, agronomic characteristics of tomato genotypes have been characterized (Abreu et al., 2006); however, there is still little information on the effect of these resistant genotypes against T. absoluta. So far, only the genotype BGH-1497 has had its strength proven, but there are few known studies on inheritance by antixenosis (Oliveira et al., 2009).

The objective of this work was to determine the inheritance of resistance by antixenosis in tomato plants to T. absoluta.

\section{Materials and Methods}

The experiment was carried out at the Universidade Federal de Viçosa (UFV), Viçosa, MG, Brazil. The tomato genotype BGH-1497 from the Banco de Germoplasma de Horticultura (Horticultural Germplasm Bank - BGH) of the UFV was used, since low preference for oviposition of $T$. absoluta had been detected in this genotype in previous studies (Oliveira et al., 2009).

The cultivar Santa Clara (Isla Sementes, Porto Alegre, RS, Brazil) was the female parent $\left(\mathrm{P}_{1}\right)$, while genotype BGH-1497 was the male parent $\left(\mathrm{P}_{2}\right)$. The seeds obtained from this crossing originated the $F_{1}$ plants. Some plants of the generation $F_{1}$ were autofecundated to produce the generations $F_{2}$, while others were crossed with BGH-1497 and 'Santa Clara' to obtain the backcross generations $\mathrm{RC}_{2}$ and $\mathrm{RC}_{1}$, respectively. Evaluations were performed for 15, 15, $16,220,64$ and 64 tomato plants of the generations $P_{1}$, $\mathrm{P}_{2}, \mathrm{~F}_{1}, \mathrm{~F}_{2}, \mathrm{RC}_{1}$ and $\mathrm{RC}_{2}$, respectively.

Seeds from parents BGH-1497 and 'Santa Clara', and from the generations $\mathrm{F}_{1}, \mathrm{~F}_{2}, \mathrm{RC}_{1}$ and $\mathrm{RC}_{2}$ were sown on a styrofoam tray with 128 cells, in a substrate with carbonized pine bark + vermiculite Bioplant (Bioplant Agrícola Ltda, Nova Ponte, MG, Brazil).

Plants from parents BGH-1497 and 'Santa Clara' and from the generations, $\mathrm{F}_{1}, \mathrm{~F}_{2}, \mathrm{RC}_{1}$ and $\mathrm{RC}_{2}$, with three definitive leaves, were transplanted to $300 \mathrm{~mL}$ plastic cups. After 30 days, the seedlings from generations $\mathrm{P}_{1}$, $\mathrm{P}_{2}, \mathrm{~F}_{1}, \mathrm{RC}_{1}, \mathrm{RC}_{2}$ and $\mathrm{F}_{2}$ were placed and equidistantly disposed inside a cage with wooden corners, covered with an organza cloth, with $3.0 \times 1.0 \times 0.8 \mathrm{~m}$ in length, width and height, respectively. The cages were placed in a greenhouse, at temperature of $25 \pm 5^{\circ} \mathrm{C}$ and air relative humidity of $75 \%$. The cultural treatments applied to the tomato plants followed the recommendations by Silva et al. (2008). The irrigation was performed twice a day, without any chemical control of pests and diseases.

The infestation was conducted with 200 adult leafminers released in each cage, regardless of sex. The evaluations were carried out after every 12 hours of exposure of the seedlings to adult leafminers, by counting the number of eggs per plant for each generation. Data from the egg count were used to generate the nonpreference index (NPI) for the oviposition of the tomato plant leafminer:

$$
\mathrm{NPI}=[(100-\mathrm{P}) /(100+\mathrm{P})] 100,
$$

in which: $\mathrm{P}$ is the percentage of oviposition, considered as $100 \%$ preference for oviposition, when the tomato plant had the highest number of eggs in the evaluations. By definition, a nonpreference index equal to zero was adopted for the plant with the highest oviposition rate.

Based on the variance analysis, the following estimates were obtained (Cruz et al., 2004): genotypic variance in generation $\mathrm{F}_{2}\left(\hat{\sigma}_{\mathrm{gF} 2}^{2}\right), \hat{\sigma}_{\mathrm{gF} 2}^{2}=\hat{\sigma}_{\mathrm{fF} 2}^{2}-\hat{\sigma}_{\mathrm{weF} 2}^{2}$; phenotypic variance in generation $F_{2}\left(\sigma_{\mathrm{fF} 2}^{2}\right)$, $\sigma_{\mathrm{fF} 2}^{2}=\sigma_{\mathrm{aF} 2}^{2}+\hat{\sigma}_{\mathrm{dF2} 2}^{2}+\hat{\sigma}_{\mathrm{weF} 2}^{2}$; environmental variance in generation $\mathrm{F}_{2}\left(\hat{\sigma}_{\mathrm{weF} 2}^{2}\right), \hat{\sigma}_{\mathrm{weF} 2}^{2}=\hat{\sigma}_{\mathrm{fP} 1}^{2}$; additive variance $\left(\hat{\sigma}_{\mathrm{aF} 2}^{2}\right), \hat{\sigma}_{\mathrm{aF} 2}^{2}=2 \hat{\sigma}_{\mathrm{gF} 2}^{2}-\left(\hat{\sigma}_{\mathrm{gRC} 1 \mathrm{P} 1}^{2}+\sigma_{\mathrm{gRC} 2 \mathrm{P} 2}^{2}\right)$; variance due to dominance deviations $\left(\sigma_{\mathrm{dF} 2}^{2}\right), \quad \hat{\sigma}_{\mathrm{dF} 2}^{2}=\sigma_{\mathrm{gF} 2}^{2}-\hat{\sigma}_{\mathrm{aF} 2}^{2}$; broad-sense heritability $\left(\mathrm{h}_{\mathrm{aF} 2}^{2}\right), \mathrm{h}_{\mathrm{aF} 2}^{2}=\hat{\sigma}_{\mathrm{gF} 2}^{2} / \hat{\sigma}_{\mathrm{fF} 2}^{2}$; narrow-sense heritability $\left(\mathrm{h}_{\mathrm{rF} 2}^{2}\right), \mathrm{h}_{\mathrm{rF} 2}^{2}=\hat{\sigma}_{\mathrm{aF} 2}^{2} / \hat{\sigma}_{\mathrm{fF} 2}^{2}$, $\mathrm{h}_{\mathrm{rF2}}^{2}=\left[\hat{\sigma}_{\mathrm{aF} 2}^{2} /\left(\hat{\sigma}_{\mathrm{aF} 2}^{2}+\hat{\sigma}_{\mathrm{dF2}}^{2}+\hat{\sigma}_{\mathrm{weF} 2}^{2}\right)\right]$. Cruz et al., 2004, obtained the following estimates for average degree of dominance (ADD):

variance-based $-\mathrm{ADD}=\left(\begin{array}{ll}2 & \hat{\sigma}_{\mathrm{dF} 2}^{2} / \hat{\sigma}_{\mathrm{aF} 2}^{2}\end{array}\right)^{0.5}$, average-based $-\mathrm{ADD}=\left\{\left[2 \overline{\mathrm{F}}_{1}-\left(\overline{\mathrm{P}}_{1}+\overline{\mathrm{P}}_{2}\right)\right] / \overline{\mathrm{P}}_{1}-\overline{\mathrm{P}}_{2}\right\}$;

and minimum number of genes involved in character determination $(\eta), \eta=\left\{\left[\mathrm{R}^{2}\left(1+0,5 \mathrm{~K}^{2}\right)\right] / 8 \hat{\sigma}_{\mathrm{gF} 2}^{2}\right\}$; in which: $\hat{\sigma}_{\mathrm{fP} 1}^{2}$ is the phenotypic variance in $\mathrm{P}_{1} ; \hat{\sigma}_{\mathrm{fP} 2}^{2}$ is the phenotypic variance in $\mathrm{P}_{2} ; \hat{\sigma}_{\mathrm{fF} 1}^{2}$ is the phenotypic variance in $\mathrm{F}_{1} ; \hat{\sigma}_{\mathrm{fF} 2}^{2}$ is the phenotypic variance in $\mathrm{F}_{2}$; $\hat{\sigma}_{\mathrm{gRClP} 1}^{2}$ is the genotypic variance in $\mathrm{RC}_{1} ; \overline{\mathrm{F}}_{1}$ is the average of $\mathrm{F}_{1} ; \hat{\sigma}_{\mathrm{gRC} 2 \mathrm{P} 2}^{2}$ is the genotypic variance in $\mathrm{RC}_{2} ; \mathrm{R}^{2}$ is the total amplitude in $\mathrm{F}_{2} ; \mathrm{K}$ is the $\mathrm{ADD} ; \overline{\mathrm{P}}_{1}$ is the average of the parent with higher magnitude; $\overline{\mathrm{P}}_{2}$ is the average of the parent with lower magnitude.

The environmental variance was estimated in $F_{2}$ through phenotypic variance in $\mathrm{P}_{1}$. The environmental variance was calculated in $\mathrm{RC}_{1}$ with the estimator 
$\left(\mathrm{VfP}_{1}+\mathrm{VfF}_{1}\right) / 2$, and the environmental variance in $\mathrm{RC}_{2}$ was calculated with $\left(\mathrm{VfP}_{2}+\mathrm{VfF}_{1}\right) / 2$.

The generation averages were analyzed with the complete and the additive-dominant models. In the complete model ( $\mathrm{m}, \mathrm{a}, \mathrm{d}$, aa, ad, dd), the parameters were estimated with the ordinary least squares method. In the additive-dominant model (m, a, d), the parameters were estimated with the weighted least squares method, in accordance with the methodology described by Cruz et al. (2004). The variances and generation averages were analyzed with the GENES software (Cruz, 2001).

In order to test the hypothesis of monogene inheritance and the presence of polygene loci (or modifiers) affecting the character, an alternative methodology based on the estimators of maximum likelihood was used (Menezes et al., 2005). In the most general model, there is a gene with higher effect, as well as polygenes with additive effects and the same dominance and environmental variances for all generations. Independent genes, polygenes and genes with greater effect, were also admitted. Based on the functions of likelihood for each model, it was possible to compose tests of interest, considering different hypotheses. The tests were carried out with the GENES software (Cruz, 2001).

\section{Results and Discussion}

A difference in the nonpreference index (NPI) was observed for the different generations obtained from the crossing between the cultivar Santa Clara and the genotype BGH-1497 $\left(\mathrm{F}_{(5,4)}=2.81, \mathrm{p}=0.017\right)$. The NPI averages observed for $\mathrm{P}_{1}, \mathrm{RC}_{1}$ and $\mathrm{RC}_{2}$ were higher than the expected ones, and an inverse response was observed for the averages of $\mathrm{P}_{2}, \mathrm{~F}_{1}$ and $\mathrm{F}_{2}$ (Table 1). The NPI average observed for the parent BGH-1497 was 38\% lower than that for the parent 'Santa Clara', indicating lower preference for the genotype in comparison to the cultivar by T. absoluta insects.

The back crossings were observed to achieve similar averages, but showed contrasting phenotypic variances (Table 1). The average degree of dominance was 1.17. Cabral et al. (2001, 2002) did not verify significant transgressive segregation in the generations of the crossings among four oat genotypes, since the genes that control certain characters are not distributed complementarily among the parents, which allows of the accumulation of favorable or unfavorable genes in the progenies. Variance-based, 5.37 genes controlling antixenosis-resistance in BGH-1497 were estimated, which indicates polygene inheritance. The inheritance of this type of resistance is the expression of genes of several loci, each contributing with a small additive effect. The significant advantage of horizontal resistance is its ability to control a wide spectrum of insect biotypes and, in opposition to vertical resistance, it shows difficulties for transferring from one genotype to another and is more stable and durable (Khush \& Panda, 1995; Vendramim \& Nishikawa, 2001).

The genotypic variance in population $F_{2}$ was attributed to additive effects due to the negative values of the variances related to the deviations of dominance, which was considered zero for the calculation of the average degree of variance-based dominance (Table 2). Robinson \& Cockerham (1965) stated that this occurs because of the impossibility of isolating the effects of the genotype-environment interaction. Several studies emphasize the importance of evaluating progenies in more than one environment to obtain more consistent estimates of the variance components, thus avoiding to overestimate the environmental variance (Carvalho et al., 2002; Coelho et al., 2010).

Linch \& Walsh (1998) reported that many authors prefer to consider negative heritability equal to zero to avoid problems in the discussion of their data, consequently, the occurrence of negative heritability is possible when genetic variance is low. Researchers should evaluate the nature of their data and decide for

Table 1. Averages of the nonpreference index (NPI) for Tuta absoluta in tomato plant generations $\mathrm{P}_{1}, \mathrm{P}_{2}, \mathrm{~F}_{1}, \mathrm{~F}_{2}, \mathrm{RC}_{1}$ and $\mathrm{RC}_{2}$ from the crossing 'Santa Clara' $\mathrm{x}$ BGH-1497, components of average and average degree of dominance.

\begin{tabular}{lc}
\hline Population & NPI \\
\hline $\mathrm{P}_{1}$ & 22.68 \\
$\mathrm{P}_{2}$ & 14.11 \\
'Santa Clara' female parent $\left(\mathrm{F}_{1}\right)$ & 23.40 \\
$\mathrm{BGH}_{1} 1497$ male parent $\left(\mathrm{F}_{2}\right)$ & 24.44 \\
$\mathrm{RC}_{1}$ & 26.16 \\
$\mathrm{RC}_{2}$ & 28.75 \\
Average of the homozygotes $(\mathrm{m})$ & 20.17 \\
Gene additive effect $(\mathrm{a})$ & 2.23 \\
Dominance deviation effect $(\mathrm{d})$ & 9.30 \\
Chi-square $\left(\chi^{2}\right)$ & $3.16^{\mathrm{ns}}$ \\
Average degree of dominance $(\mathrm{ADD})$ & 1.17 \\
Number of genes $(\eta)$ & 5.37 \\
\hline
\end{tabular}

${ }^{n}$ Nonsignificant. 
the most adequate option. In this research, zero was chosen instead of negative variance.

The estimated values of heritability were intermediate and allowed of genetic gains through the phenotypic selection of resistant individuals by antixenosis in segregant generations (Table 2). The effect of the genotype-environment interaction was not evaluated, since the experiment was conducted in only one environment. According to Allard (1960), heritability is not a property of the character, but of the population and of environmental conditions. Therefore, the values should be considered as an indication of heritability favorable to the development of tomato genotypes, which are resistant by antixenosis to tomato leafminer.

Comparing model 1 to model 5 of the inheritance tests, which confronts the existence of a gene with higher effect, it becomes evident that such a gene does exist (Table 3). Comparing model 1 to model 7 , which confronts the existence of a gene with higher effect plus polygenes, with only one gene of higher effect, there is evidence of polygenic effects. Thus, the existence of a gene with higher effect with additive and dominance effects, together with polygenes, seems to be the most adequate model to explain the inheritance of the resistance of BGH-1497 to T. absoluta. Both were significant for this work, evidencing the presence of a gene with higher effect and of polygenes as well. The analysis of the generations indicated 5.37 loci (Table 1), which is in accordance with the analysis of the models in Table 3.

Table 2. Variances of the generations $\mathrm{P}_{1}, \mathrm{P}_{2}, \mathrm{~F}_{1}, \mathrm{~F}_{2}, \mathrm{RC}_{1}$ and $\mathrm{RC}_{2}$, based on the crossing between 'Santa Clara' and BGH-1497, estimates of the components of variance of the additive-dominant model, and broad-sense heritability of the nonpreference index for T. absoluta in tomato plants.

\begin{tabular}{lc}
\hline Population & Variance \\
\hline $\mathrm{P}_{1}$ & 118.05 \\
$\mathrm{P}_{2}$ & 215.99 \\
$\mathrm{~F}_{1}$ & 395.33 \\
$\mathrm{~F}_{2}$ & 348.98 \\
$\mathrm{RC}_{1}$ & 323.99 \\
$\mathrm{RC}_{2}$ & 467.49 \\
Environmental variance $\left(\hat{\sigma}_{\mathrm{E}}^{2}\right)$ & 118.05 \\
Genotypic variance $\left(\hat{\sigma}_{\mathrm{G}}^{2}\right)$ & 230.94 \\
Additive variance $\left(\hat{\sigma}_{\mathrm{A}}^{2}\right)$ & 232.73 \\
Dominance variance $\left(\hat{\sigma}_{\mathrm{D}}^{2}\right)$ & -1.79 \\
Narrow-sense heritability $\left(\hat{\mathrm{h}}_{\mathrm{r}}^{2}\right)$ & 66.17 \\
Broad-sense heritability $\left(\hat{\mathrm{h}}_{\mathrm{a}}^{2}\right)$ & 66.69 \\
\hline
\end{tabular}

For the characteristic of gene effect, it is possible to achieve superior homozygotic genotypes from the selection in the populations derived from $\mathrm{F}_{2}$, which is of interest for a breeding program that seeks to make genotypes less attractive to tomato leafminers. Hence, it it is possible to obtain superior homozygotic genotypes by means of a selection based on the generation $\mathrm{F}_{2}$, and the gains in the selection cycles will be most likely satisfactory, since the component with an additive nature is of significant magnitude.

The phenotypic proportion of 9:7 (susceptible: resistant) was significant at $5 \%$ probability with the chi-square test, while the other phenotypic proportions were rejected (Table 4).

According to Cruz et al. (2004), the additive variance indicates how easily genetically superior genotypes can be identified, whose selection can result in more advantageous

Table 3. Hypothesis tests of hierarchical genetic models for the nonpreference index for Tuta absoluta in tomato plants.

\begin{tabular}{|c|c|c|c|}
\hline $\begin{array}{l}\text { Test between } \\
\text { models }\end{array}$ & Degree of freedom & $\begin{array}{c}\text { Chi-square } \\
\left(\chi^{2}\right)\end{array}$ & Probability \\
\hline 1 vs. 2 & 3 & 13.5 & 0.0008 \\
\hline 1 vs. 3 & 1 & 6.9 & 0.0087 \\
\hline 1 vs. 4 & 4 & 14.7 & 0.0059 \\
\hline 1 vs. 5 & 5 & 6.9 & 0.0319 \\
\hline 1 vs. 6 & 6 & 14.0 & 0.0138 \\
\hline 1 vs. 7 & 5 & 11.4 & 0.0400 \\
\hline 1 vs. 8 & 6 & 14.9 & 0.0247 \\
\hline 1 vs. 9 & 7 & 14.2 & 0.0411 \\
\hline 2 vs. 4 & 1 & 1.2 & 0.3134 \\
\hline 2 vs. 6 & 2 & 0.5 & 0.6528 \\
\hline 2 vs. 7 & 2 & (1) & $a b$ \\
\hline 2 vs. 8 & 2 & 1.4 & 0.7922 \\
\hline 2 vs. 9 & 3 & 1.7 & 0.8825 \\
\hline 3 vs. 5 & 4 & 0.0 & 0.9999 \\
\hline 3 vs. 6 & 1 & 7.42 & 0.1155 \\
\hline 3 vs. 8 & 5 & 7.0 & 0.1797 \\
\hline 3 vs. 9 & 6 & 7.74 & 0.2581 \\
\hline 4 vs. 6 & 1 & (1) & $a b$ \\
\hline 4 vs. 8 & 2 & 0.02 & 0.9894 \\
\hline 4 vs. 9 & 3 & 0.16 & 0.9842 \\
\hline 5 vs. 6 & 3 & 7.42 & 0.0598 \\
\hline 5 vs. 9 & 5 & 7.74 & 0.1714 \\
\hline 6 vs. 9 & 2 & 0.32 & 0.8521 \\
\hline 7 vs. 8 & 1 & 2.84 & 0.0917 \\
\hline 7 vs. 9 & 2 & 2.98 & 0.2254 \\
\hline 8 vs. 9 & 1 & 13.45 & 0.0002 \\
\hline
\end{tabular}


gains. As a consequence, the additive variance identifies the genotypes of tomato plants which are less attacked by tomato leafminers, namely, genotypes which are resistant by antixenosis to tomato leafminers.

By studying the genetic inheritance of the resistance of Stemphylium solani and its phytotoxin, in three cotton cultivars, Mehta \& Arias (2001) observed that epistatic effects represent $9.62 \%$ of the available variability. The authors also pointed out that, although the values of the effects are low, they should not be disregarded, because they are important to define the breeding program.

The values of the epistatic interactions can be even higher than the ones indicated by the complete model, because, according to this model, in the study of genotypic variance, the population is in Hardy-Weinberg equilibrium and neglects epistatic variances (Cruz et al., 2004). The genetic models that neglect epistatic variances, therefore, may be biased in some way (Cockerham, 1954). The epistatic components of the genetic variation, detected in this study, can be exploited by adopting back crossings to develop genotypes with superior characteristics.

The phenotypic proportion that best explained the data of this experiment was 13:3, namely, 13 susceptible to 3 resistant, because of the better adequacy of the chi-square test, allowing of the creation of two possible figures to identify the genotypes for each generation (Figure $1 \mathrm{~A}$ and $\mathrm{B}$ ).

The NPI phenotypic average in $\mathrm{P}_{1}$ was superior to that of $\mathrm{P}_{2}$, probably because $\mathrm{P}_{1}$ is a strain of tomato. That justified the use of a phenotypic variance of $\mathrm{P}_{1}$, when calculating the environmental variance in $F_{2}$, since $P_{1}$ is a commercial variety and it is in homozygosis, which is demonstrated by a smaller phenotypic variance, in comparison to the other generations.

Table 4. Chi-square test $\left(\chi^{2}\right)$ for the phenotypic proportion for antixenosis resistance to tomato leafminer, in generation $\mathrm{F}_{2}$, resulting from the crossing between 'Santa Clara' and BGH-1497(1).

\begin{tabular}{ccccccc}
\hline \multicolumn{2}{c}{ Observed frequency } & \multirow{2}{*}{ Hypothesis } & \multicolumn{2}{c}{ Expected frequency } & \multirow{2}{*}{$\chi^{2}$} \\
\cline { 1 - 3 } \multicolumn{2}{l}{ Susceptible } & Resistant & & Susceptible & Resistant & \\
\hline \multirow{2}{*}{176} & \multirow{2}{*}{44} & & $3: 1$ & 165 & 55 & $2.94^{\text {ns }}$ \\
& & $9: 7$ & 124 & 96 & $50.43^{*}$ \\
& & $13: 3$ & 179 & 41 & $0.23^{\text {ns }}$ \\
\hline
\end{tabular}

(1)Resistant (NPI $>89 \%$ ), susceptible (NPI $<89 \%) ; \chi^{2}(1,0.05)=3.84$. ${ }^{n s}$ Nonsignificant. ${ }^{*}$ Significant at $5 \%$ probability.
According to the analysis of average and variance, there are two genes that rule the resistance by antixenosis in BGH-1497 and the epistatic effects are responsible for a considerable percentage of the available genetic variability of the antixenosis resistance character (Figure 1A and B). Based on such information, it was concluded that the genotypes of the parents and generations would be in accordance with figures $1 \mathrm{~A}$ and $\mathrm{B}$. Nevertheless, due to the high

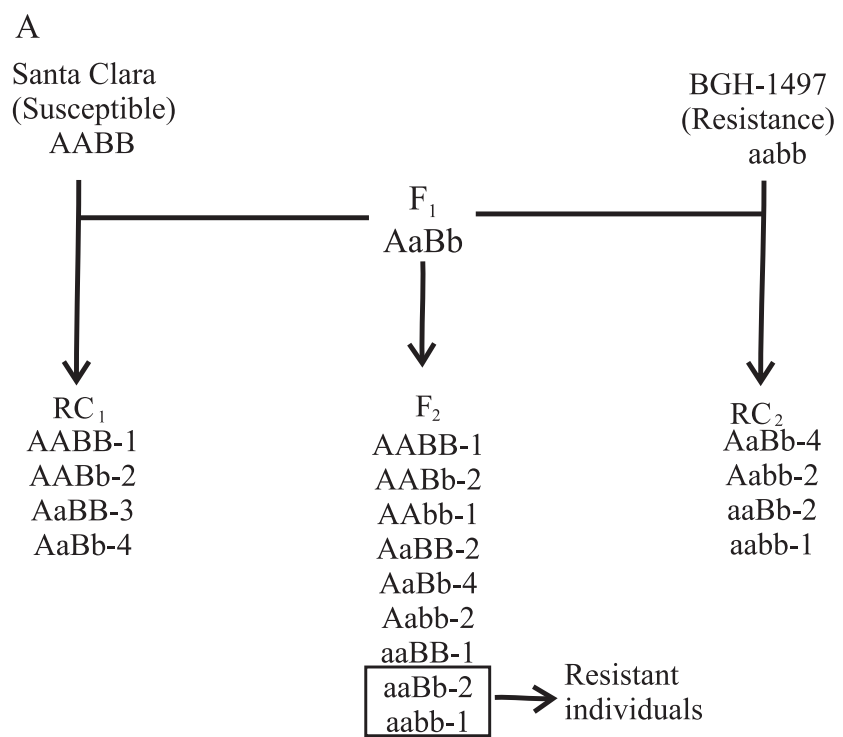

B

Santa Clara

BGH-1497

(Susceptible)

(Resistance)

Aabb $\mathrm{aaBB}$

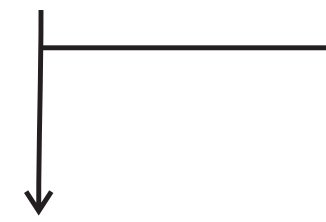

$\mathrm{RC}_{1}$

$\mathrm{AABb}-2$

AAbb-1

$\mathrm{AaBb}-4$

Aabb-2

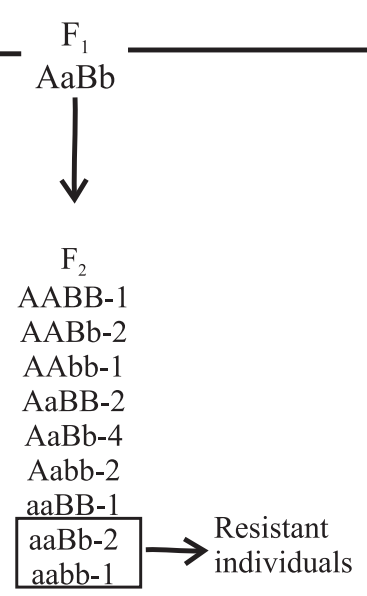

Figure 1. Possible genotypes of each generation of tomato plant, provided by the crossing between 'Santa Clara' and BGH-1497, considering the phenotypic proportion of 13:3 (AB) for susceptible and resistant genotypes respectively. 
phenotypic variability of $\mathrm{P}_{2}$, in comparison to $\mathrm{P}_{1}, \mathrm{P}_{2}$, was possibly composed of advanced strains of tomato plants, since the 13:3 proportion allows of the inference of possible genotypes of $\mathrm{P}_{2}$. Thus, $\mathrm{P}_{2}$ may show a strain with genotype aabb or a strain with genotype aaBB. In both cases, the presence of the gene allows of the manifestation of the resistance character by gene $b$ or $B$. This way, if $P_{1}$ has an AAbb genotype, and $P_{2}$ aaBB genotypes, aaBB and aaBb are responsible for tomato antixenosis resistance to $T$. absoluta in the presence of aa and, at least, one gene B (Figure 1A). Thus, supposing that $\mathrm{P}_{1}$ shows an $\mathrm{AABB}$ genotype, and $\mathrm{P}_{2}$ an aabb genotype, in the presence of aa and at least one gene $\mathrm{b}$, the genotypes aabb and aaBb give to tomato plants antixenosis resistance to tomato leafminer (Figure 1B).

Dominance effects and gene interactions are less important in autogamic species (Arias, 1986). However, nonallelic gene interactions cannot be ignored in the basic genetic mechanisms. It must be pointed out that the epistatic effects in this study were considerable, and the environmental effects were of significant magnitude. Therefore, the estimates of the genetic parameters are likely to show a substantial bias, which should be taken into consideration before any kind of breeding method is recommended for use in the studied population. Thus, more studies are necessary to define which would be the genotype of $\mathrm{P}_{2}$, aabb or aaBB.

\section{Conclusion}

The inheritance of antixenosis resistance to Tuta absoluta of the tomato genotype BGH-1497 is ruled by a gene with higher effect and polygenes in epistatic interactions, with a phenotypic proportion of 13:3 between susceptible and resistant genotypes, respectively.

\section{Acknowledgments}

To Fundação de Amparo à Pesquisa do Estado de Minas Gerais and to Conselho Nacional de Desenvolvimento Científico e Tecnológico.

\section{References}

ABREU, F.B.; SILVA, D.J.H. da; MARIM, B.G.; CARNEIRO, P.C.S.; JUHASZ, A.C.P.; DE LUCA, C.A.C.; VALENTE, R.F.; GUIMARÃES, M.A. Minimum number and best combinations of harvests to evaluate accessions of tomato plants from germplasm banks. Genetics and Molecular Biology, v.29, p.112-116, 2006.

ALLARD, R.W. Principles of plant breeding. $3^{\text {rd }}$ ed. New York: John Wiley, 1960. 485p.

ARIAS, E.R.A. Teste de escala conjunta na estimação de parámetros genéticos em soja (Glycine max (L.) Merrill). 1986. 86p. Dissertação (Mestrado) - Universidade Federal de Viçosa, Viçosa.

CABRAL, C.B.; MILACH, S.C.K.; CRANCIO, L.A.; PACHECO, M.T. Herança do peso de grãos primários e secundários de aveia. Pesquisa Agropecuária Brasileira, v.37, p.73-80, 2002.

CABRAL, C.B.; MILACH, S.C.K.; PACHECO, M.T.; CRANCIO, L.A. Herança de caracteres morfológicos de grãos primários em aveia. Pesquisa Agropecuária Brasileira, v.36, p.1133-1143, 2001.

CARVALHO, C.G.P. de; ARIAS, C.A.A.; TOLEDO, J.F.F. de; ALMEIDA, L.A. de; KIIHL, R.A. de S.; OLIVEIRA, M.F. de. Interação genótipo $\mathrm{x}$ ambiente no desempenho produtivo da soja no Paraná. Pesquisa Agropecuária Brasileira, v.37, p.989-1000, 2002.

COCKERHAM, C.C. An extension of the concept of partitioning hereditary variance for analysis of covariance among relatives when epistasis is present. Genetics, v.39, p.859-882, 1954.

COELHO, M.A. de O.; CONDÉ, A.B.T.; YAMANAKA, C.H.; CORTE, H.R. Avaliação da produtividade de trigo (Triticum aestivum L.) de sequeiro em Minas Gerais. Bioscience Journal, v.26, p.717-723, 2010.

CRUZ, C.D. Programa Genes: versão Windows: aplicativo computacional em genética e estatística. Viçosa: UFV, 2001.

CRUZ, C.D.; REGAZZI, A.J.; CARNEIRO, P.C.S. Modelos biométricos aplicados ao melhoramento genético. Viçosa: UFV, 2004. 480p.

DHILLON, M.K.; SHARMA, H.C.; SINGH, R.; NARESH, J.S. Mechanisms of resistance to shoot fly, Atherigona soccata in sorghum. Euphytica, v.144, p.301-312, 2005.

DUVICK, D.N. Plant breeding: past achievements and expectations for the future. Economic Botany, v.40, p.289-298, 1986.

FANCELLI, M.; VENDRAMIM, J.D.; FRIGHETTO, R.T.S.; LOURENÇÃO, A.L. Exsudato glandular de genótipos de tomateiro e desenvolvimento de Bemisia tabaci (Genn.) (Sternorryncha: Aleyrodidae) biótipo B. Neotropical Entomology, v.34, p.659-665, 2005.

FANCELLI, M.; VENDRAMIM, J.D.; LOURENÇÃO, A.L. Oviposição e dispersão de ninfas de Bemisia tabaci biótipo B em genótipos de tomateiro. Bragantia, v.67, p.933-939, 2008.

FRANÇA, F.H.; VILLAS BÔAS, G.L.; CASTELO BRANCO, M.; MEDEIROS, M.A. Manejo integrado de pragas. In: SILVA, J.B.C. da; GIORDANO, L. de B. (Ed.). Tomate para processamento industrial. Brasília: Embrapa Comunicação para Transferência de Tecnologia; Embrapa Hortaliças, 2000. p.112-127.

FRELICHOWSKI JUNIOR, J.E; JUVIK, J.A. Inheritance of sesquiterpene carboxylic acid synthesis in crosses of Lycopersicon hirsutum with insect-susceptible tomatoes. Plant Breeding, v.124, p.277-281, 2005 . 
KHUSH, G.S.; PANDA, N. Host plant resistance to insects. Wallingford: CAB International, 1995. 431p.

LEITE, G.L.D.; PICANÇO, M.; JHAM, G.N.; MARQUINI, F. Intensity of Tuta absoluta (Meyrick, 1917) (Lepidoptera: Gelechiidae) and Liriomyza spp. (Diptera: Agromyzidae) attacks on Lycopersicum esculentum mill. Leaves. Ciência e Agrotecnologia, v.28, p.42-48, 2004.

LINCH, M.; WALSH, B. Genetics and analysis of quantitative traits. Sunderland: Sinauer Associates, 1998. 980p.

MEHTA, Y.R.; ARIAS, C.A.A. Herança da resistência a Stemphylium solani e insensibilidade a sua fitotoxina em cultivares de algodoeiro. Fitopatologia Brasileira, v.26, p.761-765, 2001.

MENEZES, C.B. de; MALUF, W.R.; AZEVEDO, S.M. de; FARIA, M.V.; NASCIMENTO, I.R.; NOGUEIRA, D.W.; GOMES, L.A.A.; BEARZOTI, E. Inheritance of parthenocarpy in summer squash (Cucurbita pepo L.). Genetics and Molecular Research, v.4, p.39-46, 2005.

MICHEREFF FILHO, M.; VILELA, E.F. Traça-do-tomateiro, Tuta absoluta (Lepidoptera: Gelechiidae). In: VILELA, E.F.; ZUCCHI, R.A.; CANTOR, F. (Ed.). Histórico e impacto das pragas introduzidas no Brasil. Ribeirão Preto: Holos, 2001. p.81-84.

MOREIRA, G.R.; SILVA, D.J.H. da; PICANÇO, M.C.; PETERNELLI, L.A.; CALIMAN, F.R.B. Divergência genética entre acessos de tomateiro infestados por diferentes populações da traça-do-tomateiro. Horticultura Brasileira, v.23, p.893-898, 2005.

OLIVEIRA, F.A.; SILVA, D.J.H. da; LEITE, G.L.D.; JHAM, G.N.; PICANÇO, M.C. Resistance of 57 greenhouse-grow accessions of Lycopersicon esculentum and three cultivars to Tuta absoluta (Meyrick) (Lepidoptera: Gelechiidae). Scientia Horticulturae, v.119, p.182-187, 2009.

RESENDE, J.T.V. de; MALUF, W.R.; CARDOSO, M. das G.; FARIA, M.V.; GONCALVES, L.D.; NASCIMENTO, I.R. do. Resistance of tomato genotypes with high level of acylsugars to Tetranychus evansi Baker \& Pritchard. Scientia Agricola, v.65, p.31-35, 2008.

ROBINSON, H.F.; COCKERHAM, C.C. Estimación y significado de los parametros genéticos. Fitotecnia Latinoamericana, v.2, p.23-38, 1965.

SILVA, D.J.H. da; ABREU, F.B.; CALIMAN, F.R.B.; ANTÔNIO, A.C.; PATEL, V.B. Tomatoes: origin, cultivation techniques and germplasm resources. In: PREDDY, V.R.; WATSON, R.R. (Ed.). Tomatoes and tomato products. Plymouth: Science Publishers, 2008. p.3-25.

SIQUEIRA, H.A.A.; GUEDES, R.N.C.; PICANÇO, M.C. Insecticide resistance in populations of Tuta absoluta (Lepidoptera: Gelechiidae). Agricultural and Forest Entomology, v.2, p.147-153, 2000.

TOSCANO, L.C.; BOIÇA JUNIOR, A.L.; MARUYAMA, W.I. Nonpreference of whitefly for oviposition in tomato genotypes. Scientia Agricola, v.59, p.677-681, 2002.

VENDRAMIM, J.D;; NISHIKAWA, M.A.N. Melhoramento para resistência a insetos. In: NASS, L.L.; VALOIS, A.C.C.; MELO, I.S. de; VALADARES-INGLIS, M.C. (Ed.). Recursos genéticos e melhoramento - plantas. Rondonópolis: Fundação MT, 2001. p.737-781.

Received on July 10, 2010 and accepted on Dezember 30, 2010 